National Centre itself and in those attached to it such as the Laboratories of Bellevue and of Gif-sur-Yvette, the Centre for Nuclear Research, Strasbourg, and the Centre of Scientific, Industrial and Maritime Research, Marseilles, as well as the activities of the various scientific Commissions. The report displays an impressive range of scientific activities, but seldom gives more than the titles of investigations, and lists of published papers are not included.

\section{Scientific Research in Belgium}

THE thirty-fifth annual report of the National Foundation for Scientific Research, Brussels, covers the year ended September 30,1962 , in which grants totalling some 70 million francs were authorized (Pp. 349. Brussels: Fonds National de la Recherche Scientifique, 1963). For 1962-63 grants and subsidies totalling 85 million francs have been budgeted. A special grant of 100,000 francs was made to the Scientific Station of Jungfraujoch, where biological investigations have been resumed. Grants totalling 17.5 million francs were made to the Foundation for Scientific Medical Research: a list of individual recipients of grants and of the subjects of their investigations is included in the report. Grants totalling some 3.7 million francs have also been made for radiobiological research with isotopes and for cancer research at the Universities of Brussels, Ghent, Liège and Louvain, and in all some 24 million francs were awarded during the year for research in the hospitals attached to these universities and in other hospitals and special institutes. The bulk of the report comprises annexes, including an alphabetical list of the 593 recipients of grants, their subjects of investigation and publications during the year, as well as those of 146 foreign recipients of grants, 25 of whom were outside Europe. The report gives the usual details of membership of scientific commissions, etc.

\section{The Nordisk Institut for Teoretisk Atomfysik:}

AT the end of the academic year 1961-62 Nordita (Nordisk Institut for Teoretisk Atomfysik) completed its fifth year, though it is still continuing on an interim basis (Annual Reports, 1960-61 (pp. 20), and 1961-62 (pp. 32). Copenhagen: Nordita: Nordisk Institut for Teoretisk Atomfysik, 1963). The Board consisted of professors from Denmark, Finland, Iceland, Norway and Sweden, with the late Prof. Niels Bohr as chairman. Mr. L. Neilson of the Danish Ministry of Finance acted as secretary to the Board, and Dr. G. Funke, secretary-general of the Swedish A.tomic Energy Research Council, Stockholm, assisted the Board in an advisory eapacity. On June 30, 1962, the scientific staff of Nordita consisted of the director, C Moller, G. E. Brown, B. R. Mottleson, L. Rosenfeld, S. Rozental and A. Winther. Seventeen Research Fellows held appointments during the year. Two visiting professors, R. E. Cutkosky from Pittsburg and E. H. Wichmann from Berkeley, gave lectures and guided the Fellows in their work. The titles of the various courses of lectures, including those given at the Institute for Theoretical Physics, University of Copenhagen, and of the colloquia, together with the papers published and issued as Nordita Publications and five volumes of lesture notes, are listed in detail in the annual report, which as usual is printed both in Danish and English. The publications and lecture notes are obtainable free of charge by institutions and physicists interested.

\section{The Organization for European Co-operation and Development}

THE Organization for European Co-operation and Development, which on September 30, 1961, succeeded the Organization for European Economic Co-operation, is briefly but fully described in an admirable brochure under that title (Pp. 254. Paris: Organization for Economic Co-operation and Development, 1963). To the three chapters which describe successively the history of the Organization, its aims and tasks, and its structure and functions-the last of which sets out the functions of the Committee of Scientific and Technical Personnel, the Committee for Scientific Research, the Industry Committee, the Energy Committee, and the European Nuclear Energy Agency - there are appended the convention establishing the Organization, the rules of procedure, the statute of the European Nuclear Energy Agency and the text of the European Monetary Agreement and the Codes of Liberalization of Capital Movements and of Current Invisibles.

\section{Radiation Protection Norms}

REVISED radiation protection norms were approved by the Council of the Organization for Economic Co-operation and Development on December 18, 1961, in place of those previously adopted on June 12,1959 . The revised norms are given in the booklet Radiation Protection Norms (Pp. 44. Paris: European Nuclear Energy Agency, Organization for Economic Co-operation and Development, 1963). They were prepared by the Health and Safety SubCommittee of the Organization for Economic Co-operation and Development European Nuclear Energy Agency, and take account of recent developments in scientific knowledge and the latest Recommendations of the International Commission on Radiological Protection. Some of the maximum permissible dose values and most of the limits of concentration of radionuclides in drinking water and in air inhaled have been altered, but they are still based on the same principles as those previously adopted. The four main sections of the booklet deal with occupational exposure in controlled areas, exp osure of special groups of the population, exposure of individual members of the population, and exposure of the population as a whole, and the appendixes list specific data regarding maximum permissible doses and concentrations of radionuclides in drinking-water and in air inhaled. The maximum permissible whole-body dose for persons in controlled areas is governed by the formula $D=5(N-18)$, where $D$ is the tissue dose in rems and $N$ is the person's age in years. Protective devices should be based on an average weekly dose of $0.1 \mathrm{rem}$ and the maximum dose accumulated during any thirteen consecutive weeks must not exceed 3 rems. There are permitted variations in certain circumstances. The maximum permissible whole-body dose for persons not in controlled areas varies from 0.5 rem per annum according to the particular group, and for all individual members of the general population is $0.5 \mathrm{rem}$ per annum. The maximum permissible genetic dose for the population as a whole is 5 rems per capita accumulated to the age of thirty years. The booklet does not indicate where the revised norms differ specifically from those of June 1959.

\section{Co-ordinate Colour Identification for Industry}

THERE has long been in industry and science a need for a precise method of classifying and identifying colours. The National Bureau of Standards (NBS) Technical Note No. 152 (Pp. ii +9 . Washington, D.C.: Government Printing Office, 1962. 15 cents), entitled Co-ordinated Color Identifications for Industry, by $\mathrm{K}$. L. Kelly, describes a method of co-ordinating the five levels of fineness of colour designation, which was developed by the Inter-Society Colour Council Subcommittee (ISCC) for Problem 23, "The Expression of Historical Colour Usage". It is based on the ISCC-NBS method of designating colours given in the National Bureau of Standards Circular 553 (1955), which also includes a dictionary of colour names, and it lists the methods for changing from one level to another. Examples are given of the use of each level.

\section{Ion-Atom Collisions}

The National Bureau of Standards Technical Note No. 185, entitled Lectures on Ion-Atom Collisions, by M. R. C. McDowell, at present at Royal Holloway College, London, consists of six lectures delivered at the Joint 